\title{
The ergonomic and legal aspects of the heritage of the state of Pernambuco - Brazil
}

\author{
Terezinha de Jesus Pereira da Silva ${ }^{\mathrm{a}}$ and Augusto Eugenio Paashaus Neto ${ }^{\mathrm{b}}$ \\ ${ }^{a}$ Department of Architecture and Urbanism, Federal University of Pernambuco, Campus da UFPE, s/n-Recife- \\ PE - Brazil. ZIP Code: 50670-901 E-mail:terezinha_psilva@hotmail.com \\ ${ }^{\mathrm{b}}$ Legal Department, Fundarpe - Foundation of Historical and Artistic Heritage of Pernambuco. Rua da Aurora, \\ 463/469, Boa Vista, Recife - PE - Brasil. ZIP Code: 50.050-000. E-mail: augustopaashaus.adv@gmail.com
}

\begin{abstract}
This paper aims to demonstrate the situation of the buildings declared a historical landmark by the government spheres in the state of Pernambuco, and how they attend the norms of accessibility for those with special needs. The methodology of the research contemplated a sample of 46 heritage buildings, approximately $16 \%$ of the universe of properties, which are around 268. In turn, these were limited to Recife's Metropolitan Region Area - RMR comprising 30\% of the 153 properties of the municipalities of: Cabo de Santo Agostinho, Igarassu, Itamaracá, Ipojuca, Jaboatão dos Guararapes, Moreno, Olinda, Paulista, Recife and São Lourenço da Mata. From the specific forms set up based on the theoretical reference, as well as graphics and photographic records were assessed the aspects of both internal and external accessibility, displacement, (visual) orientation, and the use of space and equipment. In the analysis of different types was assembled a summary table ranking the samples in accessible, partially accessible and not accessible. As general results were found that from the 46 properties examined, $2(5 \%)$ are accessible, $16(35 \%)$ are partially accessible and $28(60 \%)$ are not accessible. Such data, although sample, shows that the majority of heritage properties does not provide access to people physically disabled or with reduced mobility signaling for professionals, managers and society institutions on the need to reduce physical barriers in such heritage.
\end{abstract}

Keywords: accessibility, ergonomics, Fundarpe, heritage, Pernambuco.

\section{Introduction}

The concept of ergonomics that emerged in the period after World War II was more focused on studies of adapting work to man [6]. With the deepening of studies between humans and their working environments, in order to make it more safe, healthy and productive the approaches of ergonomics have embroidery both relations-oriented services, the use of various equipment and the use for day to day lives [6].

Among the new fields of application of ergonomics in building and public spaces, accessibility started to be has to be focused by the Federal Constitution of Brazil/ 1988 [1] as in common standards like the group of urban instrument formed by the Master Plans, Municipal Laws of Land Use, Codes of Construction Works and Postures and Transport Plans [2]. These instruments aim to improve the quality of the spaces of people who use them and make them with comprehensive and consistent use to all.

The creation of laws aimed for accessibility represent an advance, but even with them existing, is no guarantee that the adaptation time for compliance is being followed. Among the areas that have yet not fully complied with the laws of accessibility we have to preserve the historical and artistic heritage of the State of Pernambuco - Brazil either at the federal, state or municipal levels.

\subsection{The Laws of accessibility}

Looking at the timeline of the laws on accessibility in Brazil, we find that they have evolved from a specific focus for people with disabilities or reduced mobility to take part in various spheres of research and planning. 
The record of access to public buildings and spaces to people with special needs was part of the Constitutional Amendment $\mathrm{N}^{\mathrm{o}} 12$ from 17th October 1978 [3] of the revoked Constitution of 1967. In turn, the Law $\mathrm{N}^{0} 7405$ of November 12th, 1985, established the placement of the international symbol of Access [2].

The 1988 Constitution called for in Article 5, section $\mathrm{XV}$, the guarantee to come and go at anyone. In turn, Article 227 of the Constitution of 88, paragraph 2 stated that "The law shall regulate construction standards for streets and public buildings .... to ensure appropriate access to persons with disabilities" [ 1]. Also related to the subject the Article 244 provides for the adaptation of streets of public buildings and other determinations [1]. The Constitution of the State of Pernambuco, 1989, also provides on Chapter III, about Urban Policy in Article 144, § 2 item $\mathrm{f}$ defined the "adequate access of people with disabilities to public buildings, streets and public transportation"[9].

The Law No 10048 of November $8^{\text {th }}, 2000$, established a priority service for people over 60 years and those with special needs, and the accessibility on the streets and public spaces' restrooms [2].

Law No 10098 of December 19th 2000, emphasized the removal of barriers and obstacles on roads, public spaces, buildings, transportation and communication [2]. On the other hand, the Decree No. 5296 of December $2^{\text {nd }}, 2004$ regulates the Federal Laws n 10.048/2000 and 10.098/2000, still in line with the precepts of ABNT NBR 9050:2004, set deadlines for implementation of the norms, ranging from immediately to 48 months (2008) after publication.

Special emphasis should be given to the Normative Instruction N. 1, of November $25^{\text {th }}, 2003$, from IPHAN-Institute for National Artistic and Historical Heritage which set guidelines for accessibility in the cultural property buildings taken care by the federal level stimulating solutions aimed for an universal design, beyond the concern of the non mischaracterization of the property [7]. As main points of the Normative N. 1 adopted for the analysis of the heritage we have: a) check the type of barrier (stairs, step, ramp outside the norm), b) the existence of rail, c) support equipment (platform lift, phone, etc..) d) signs (visual, tactile and sound), e) route autonomously.

Some guidelines from the Ministry of Tourism [10] were also used as analysis variables such as: verification of accessible restrooms and types of floor (non-skid, anti-hectic, directional and of warning).

From the compliance of the points of the Normative Instruction N. 1 and the guidelines of the Ministry of Tourism that synthesize the various laws of accessibility were defined three classifications for the heritages: accessible (that meets all the requirements for accessibility), Partially Accessible (when you have parts or sections that allow accessibility) and is not accessible (it has several barriers).

\section{Methodology for assessment of listed items in the State of Pernambuco}

According to a survey of FUNDARPE Foundation of Historical and Artistic Heritage of Pernambuco [4] the 277 heritages of the state, in federal and state level, have spread out across the coast to the hinterland and with a higher concentration in the Recife's Metropolitan Region area- RMR.

The aspects of accessibility assessments were made only for the sample of 46 heritages from the RMR checking how the access displacements occurs, the guidelines (visual) and the use of the spaces and equipments [5], comparing with the attendance of the laws.

\subsection{Situation of the universe of study}

The study area is located in Pernambuco State, in Recife's Metropolitan Region, in the northeast region of Brazil / South America (see Images 1, 2 and 3).

Samples aims to address the majority of municipalities (see Table 1). These were selected to cover the following types: mill, school, railway station, college, fort, gym, hospital, church, market, museum, palace, bridge, square, headquarters, residence, theater, Afican roots religion temples and towns. 


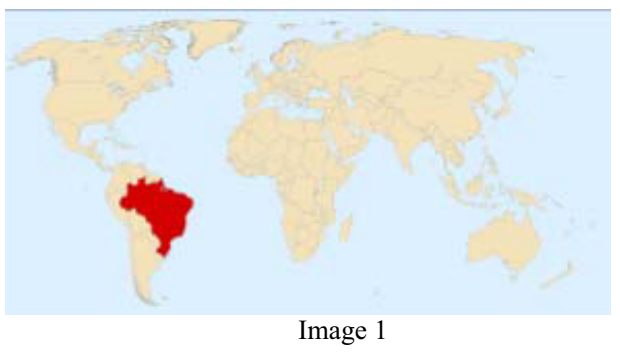

Brazil's situation in Latin America

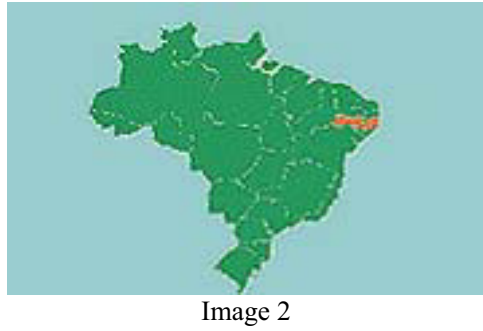

Location of Pernambuco, Brazil

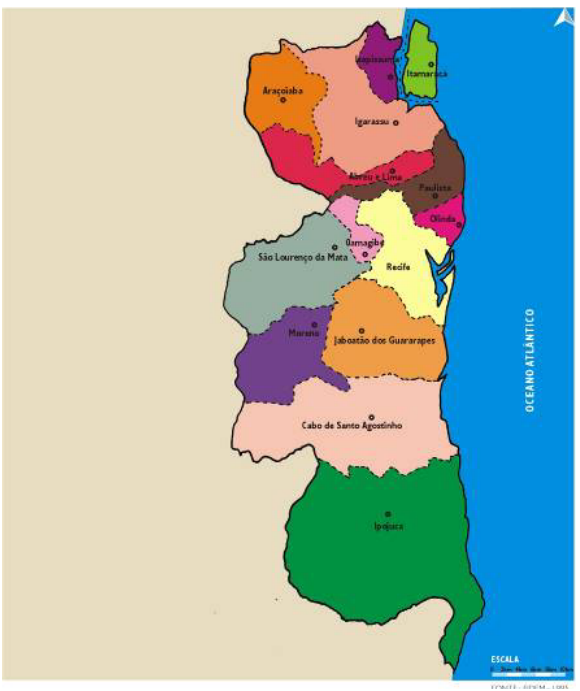

Image 3.

Situation in Recife's Metropolitan Region - PE

The amount of heritages recorded in Table 1 is over the represented, because the terms smallholding, architectural and landscape emsembles, town, village and park in most cases include many properties. For the purpose of the survey were selected within the groups just a few elements considered most representative.
Table 1

Samples of the Properties in Recife's Metropolitan Region

\begin{tabular}{|l|c|c|}
\hline Cities & Heritages & Samples \\
\hline 1 Araçoiaba & - & - \\
\hline 2 Abreu e Lima & - & - \\
\hline 3 Cabo de Santo Agostinho & 7 & 3 \\
\hline 4 Camaragibe & 2 & - \\
\hline 5 Igarassu & 8 & 6 \\
\hline 6 Ipojuca & 2 & 1 \\
\hline 7 Itamaracá & 5 & 2 \\
\hline 8Itapissuma & - & - \\
\hline 9 Jaboatão dos Guararapes & 7 & 2 \\
\hline 10 Moreno & 2 & - \\
\hline 11 Olinda & 17 & 6 \\
\hline 12 Paulista & 8 & 2 \\
\hline 13 Recife & 89 & 22 \\
\hline 14 São Lourenço da Mata & 2 & 2 \\
\hline Distrito de Fernando de Noronha & 4 & - \\
\hline Total & 153 & 46 \\
\hline
\end{tabular}

Each selected heritage, in most cities was analyzed in loco, using the form. The main issues raised were: name, location, level of heritage, number of blocks and floors, use, number of lifts / ramps / stairs and variables to check the aspects of accessibility (outside access sidewalks, type of floor, curb and lowered ramps, tactile warning signals and interference, widths of doors and passageways, accessible restrooms, signage, parking and other facilities available) according to specified theoretical framework, and graphic records (sketches) and photographic.

\section{Accessibility studies in heritages}

The application of the forms in the selected municipalities was summarized in tables that highlighted the identity of the property, the type and classifications: accessible, partially accessible and not accessible.

The city of Cabo de Santo Agostinho was summarized by Table 2 and images 4 to 8 .

The samples of the heritages of Igarassu are presented in Table 3 and Imagess 9 to 13 .

Ipojuca has its heritage represented on Table 4.

The city of Itamaracá is exemplified on Table 5 and Image 14.

The heritages from Jaboatão dos Guararapes are listed on Table 6 and Image 15.

For the city of Olinda the sample is represented on Table 7 and Images 16 and 17.

The sample for the city of Paulista is synthesized on Table 8 and Images 18 and 19. 
Table 2

Cabo de Santo Agostinho

\begin{tabular}{|c|c|c|c|c|}
\hline $\begin{array}{l}\text { Name of the } \\
\text { heritage }\end{array}$ & Type & $\begin{array}{l}\frac{0}{0} \\
\frac{0}{0} \\
0 \\
0 \\
\frac{0}{4}\end{array}$ & 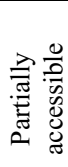 & z \\
\hline \multirow[t]{3}{*}{$\begin{array}{l}1 \text { Massangana's Mill } \\
\text { Images } 4 \text { and } 5\end{array}$} & $\begin{array}{l}\text { House of the } \\
\text { mill }\end{array}$ & & $\mathrm{X}$ & \\
\hline & Chapel & & & $\mathrm{X}$ \\
\hline & Administration & & & $\mathrm{X}$ \\
\hline \multirow{2}{*}{$\begin{array}{l}\text { 2Church of Nossa } \\
\text { Senhora de Nazaré } \\
\text { Images } 6 \text { and } 7\end{array}$} & Church & & & $\mathrm{X}$ \\
\hline & $\begin{array}{c}\text { Ruins of the } \\
\text { Convent }\end{array}$ & & & $\mathrm{X}$ \\
\hline $\begin{array}{l}3 \text { Vila Operária de } \\
\text { Pontezinha }\end{array}$ & Town & & & $\mathrm{X}$ \\
\hline
\end{tabular}

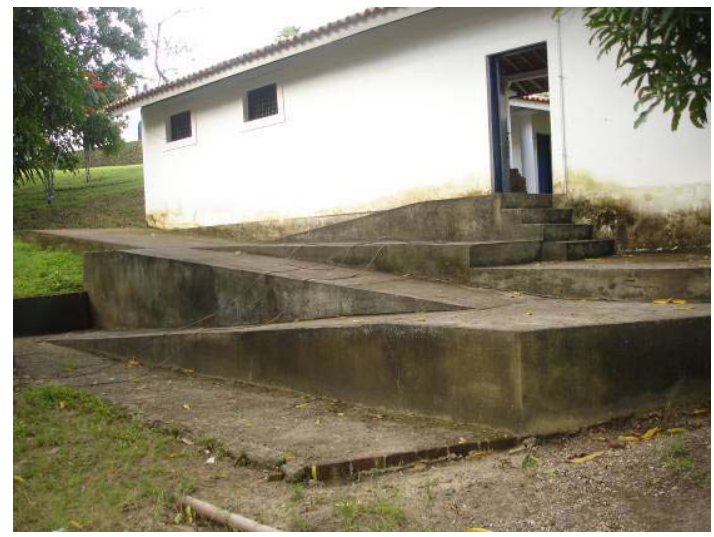

Image 4

Ramp of the Casa Grande in Massangana's

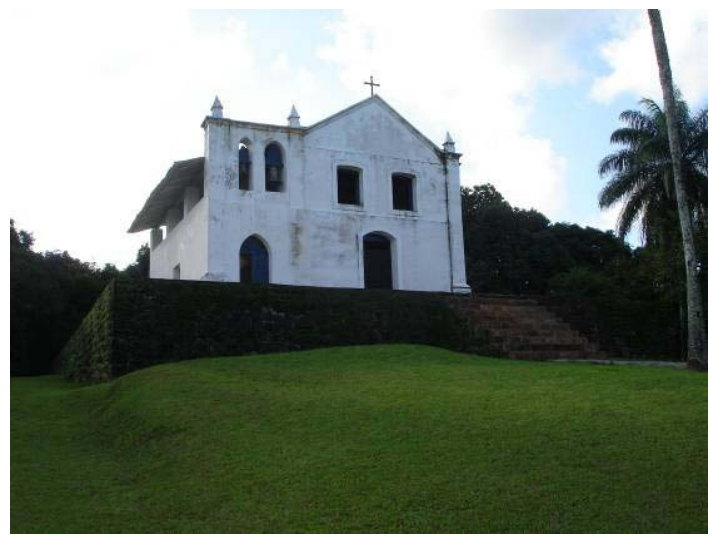

Image 5

Steps of the Chapel of the Massangana's Mill

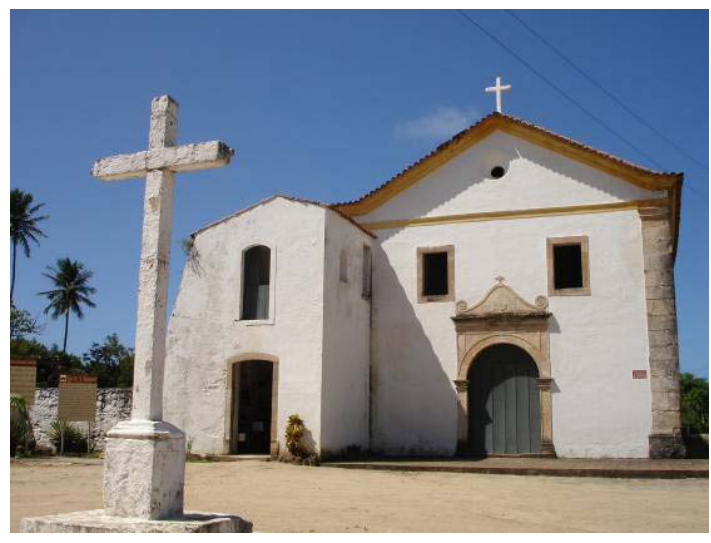

Image 6

Steps of the Church of Nossa Senhora de Nazaré

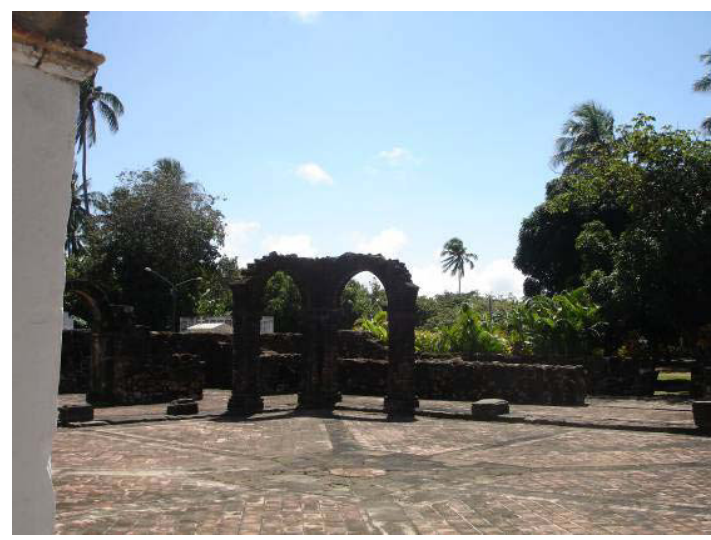

Image 7

Steps in the ruins of the Convent

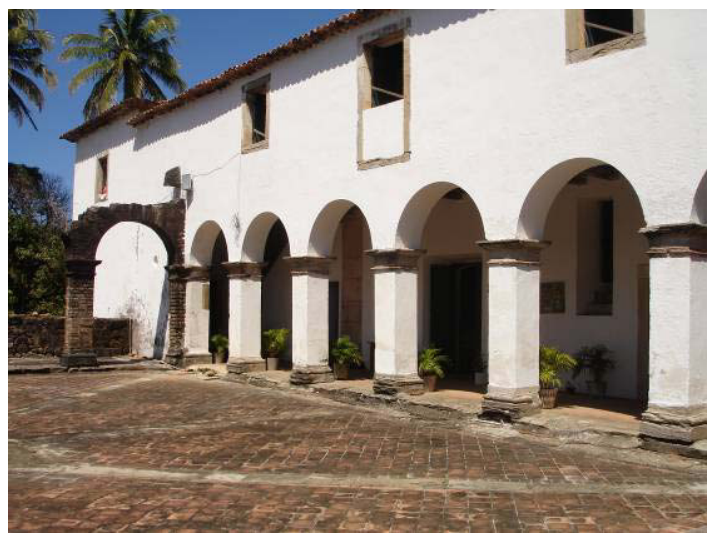

Image 8

Steps in the ruins of the Convent

The city of Recife is represented by a sample of its heritages listed in Table 9 and Images 20 and 21. 
Table 3

Igarassu

\begin{tabular}{|c|c|c|c|c|}
\hline $\begin{array}{l}\text { Name of the } \\
\text { heritage }\end{array}$ & Type & 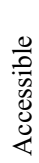 & 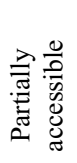 & $\vec{z} \frac{0}{0}$ \\
\hline $\begin{array}{l}\text { 1 Sobrado do } \\
\text { Imperador } \\
\text { (Patrimony House) - } \\
\text { Image } 9\end{array}$ & Residence & & $\mathrm{X}$ & \\
\hline $\begin{array}{l}2 \text { Santo Antônio's } \\
\text { Convent- Image10 }\end{array}$ & $\begin{array}{c}\text { Church and } \\
\text { Convent }\end{array}$ & & & $\mathrm{X}$ \\
\hline $\begin{array}{l}3 \text { Recolhimento do } \\
\text { Sagrado Coração de } \\
\text { Jesus and Nossa Sra. } \\
\text { da Conceição } \\
\text { Church Image11 }\end{array}$ & $\begin{array}{c}\text { Church and } \\
\text { Convent }\end{array}$ & & & $\mathrm{X}$ \\
\hline $\begin{array}{l}4 \text { Museum of } \\
\text { Igarassu Image } 11\end{array}$ & Museum & & & $\mathrm{X}$ \\
\hline $\begin{array}{l}5 \text { Cosme e Damião } \\
\text { Church Image } 12\end{array}$ & Church & & & $\mathrm{X}$ \\
\hline $\begin{array}{l}6 \text { Department of } \\
\text { Culture and Sports } \\
\text { Image } 13\end{array}$ & Residence & & & $\mathrm{X}$ \\
\hline
\end{tabular}

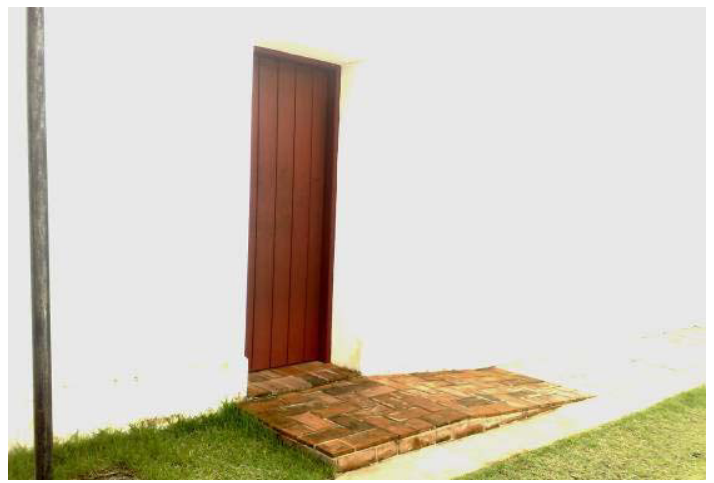

Image 9. Ramp of access to the ground floor of the Sobrado do Imperador

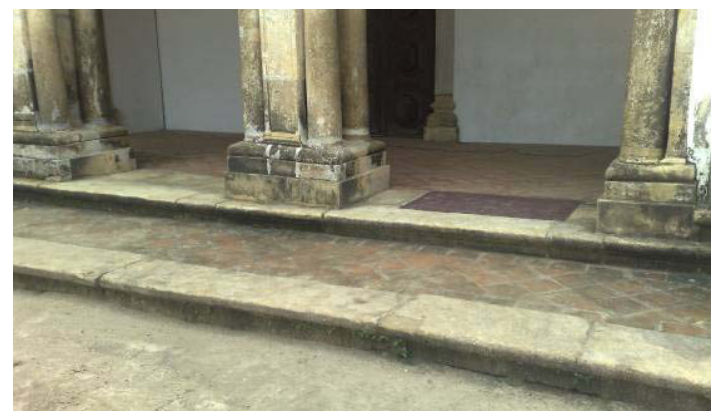

Image10. Steps to access the church and convent

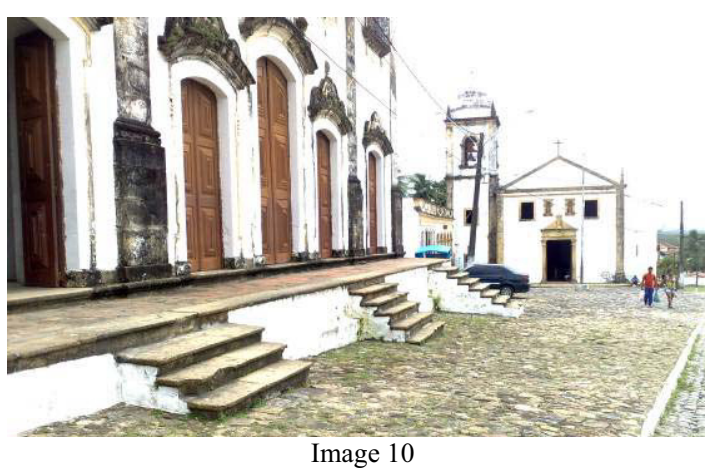

Steps to access the church and convent

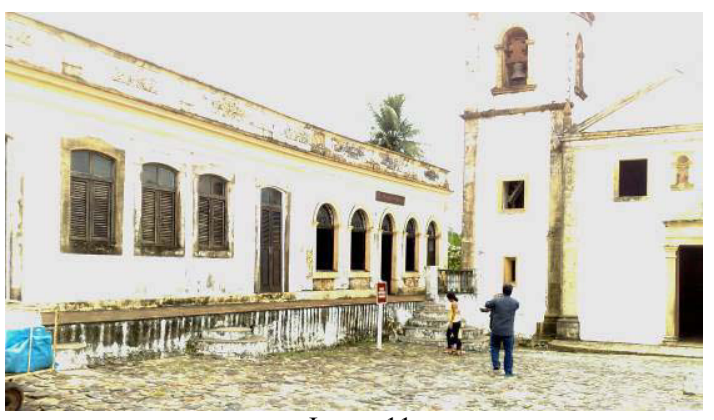

Image 11

Steps to access the museum

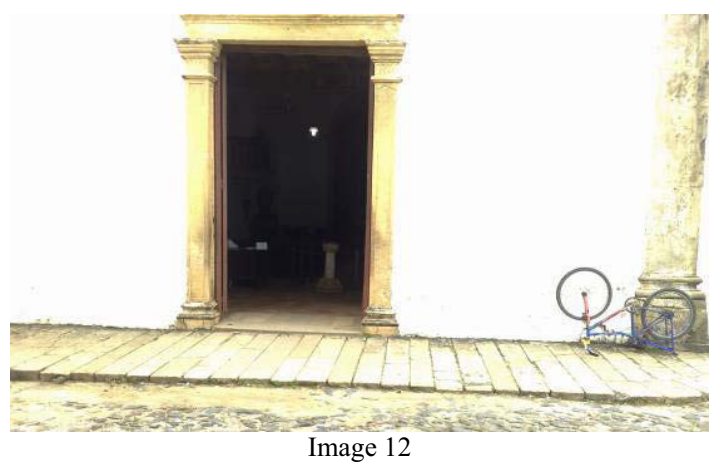

Steps to access the church Cosme e Damião

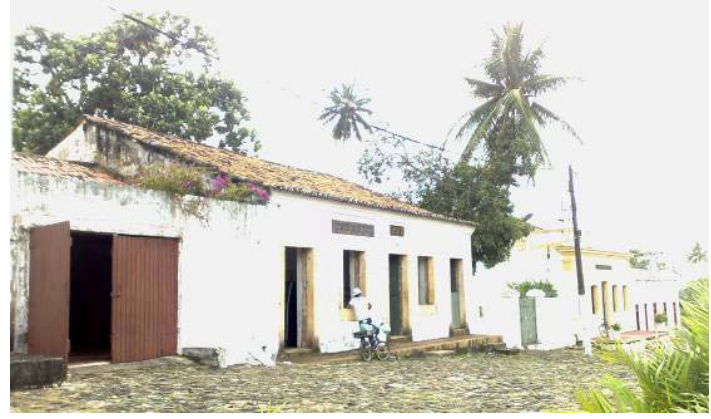

Image 13

Access steps to the Secretariat of Culture 
Table 4

Ipojuca

\begin{tabular}{|c|c|c|c|c|}
\hline \multicolumn{5}{|c|}{ Ipojuca } \\
\hline heritage & Іуре & 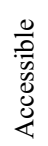 & 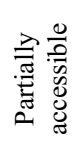 & 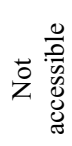 \\
\hline $\begin{array}{l}1 \text { Convent and } \\
\text { Church of Santo } \\
\text { Cristo }\end{array}$ & $\begin{array}{c}\text { Church and } \\
\text { convent }\end{array}$ & & & $\mathrm{X}$ \\
\hline
\end{tabular}

Table 5

Itamaracá

\begin{tabular}{|c|c|c|c|c|}
\hline $\begin{array}{l}\text { Name of the } \\
\text { heritage }\end{array}$ & Type & 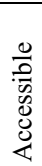 & 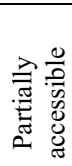 & 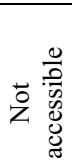 \\
\hline $\begin{array}{l}1 \text { Fortaleza de Santa } \\
\text { Cruz or Forte } \\
\text { Orange }\end{array}$ & Fort & & & $\mathrm{X}$ \\
\hline $\begin{array}{l}2 \text { Church of Nossa } \\
\text { Senhora da } \\
\text { Conceição - Vila } \\
\text { Velha }\end{array}$ & Church & & & $\mathrm{X}$ \\
\hline
\end{tabular}

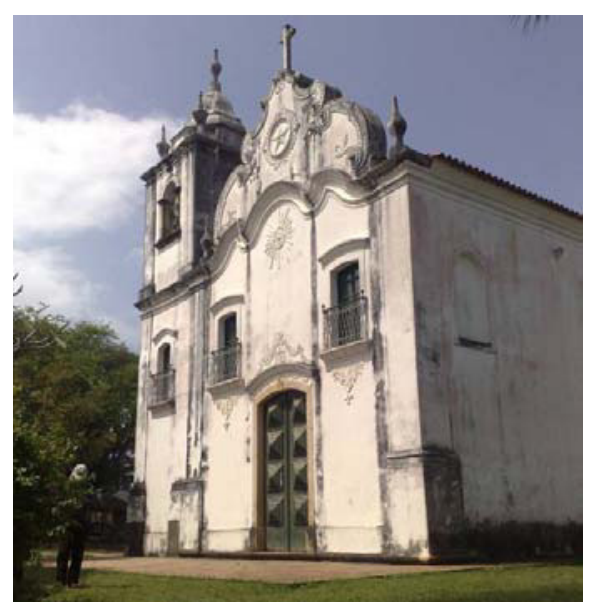

Image 14

Steps to access the church of Nossa Senhora da Conceição

Table 6

Jaboatão dos Guararapes

\begin{tabular}{|c|c|c|c|c|}
\hline $\begin{array}{l}\text { Name of the } \\
\text { heritage }\end{array}$ & Type & 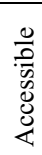 & 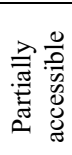 & z \\
\hline $\begin{array}{l}1 \text { Church of N. Sra } \\
\text { dos Prazeres }\end{array}$ & Church & & & $\mathrm{X}$ \\
\hline 2 Church of Piedade & Church & & & $\mathrm{X}$ \\
\hline
\end{tabular}

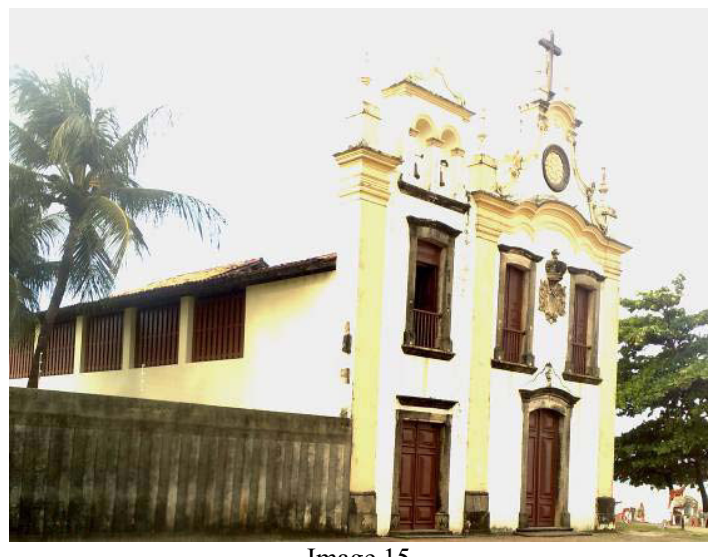

Image 15

Steps to access the church of Nossa Senhora da Piedade

Table 7

Olinda

\begin{tabular}{|c|c|c|c|c|}
\hline $\begin{array}{l}\text { Name of the } \\
\text { heritage }\end{array}$ & Type & 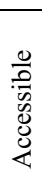 & 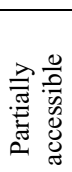 & 艺 \\
\hline $\begin{array}{l}\text { 1 Seminário de } \\
\text { Olinda and Nossa } \\
\text { Senhora da Graça's } \\
\text { Church }\end{array}$ & $\begin{array}{l}\text { Seminary and } \\
\text { Church }\end{array}$ & & & $\mathrm{X}$ \\
\hline $\begin{array}{l}2 \text { Palácio do Bispo } \\
\text { de Olinda and } \\
\text { Museu de Arte } \\
\text { Sacra -MASPE }\end{array}$ & Museum & & & $\mathrm{X}$ \\
\hline $\begin{array}{l}3 \text { Museu de Arte } \\
\text { Contemporânea } \\
\text { MAC }\end{array}$ & Museum & & & $\mathrm{X}$ \\
\hline $\begin{array}{l}4 \text { Igreja Abacial do } \\
\text { Mosteiro de São } \\
\text { Bento }\end{array}$ & Church & & & $\mathrm{X}$ \\
\hline $\begin{array}{l}5 \text { Forte de São } \\
\text { Francisco or do } \\
\text { Queijo - Fortim }\end{array}$ & Fort & & & $\mathrm{X}$ \\
\hline 6 Rua Amparo ,28 & Residence & & & $\mathrm{X}$ \\
\hline
\end{tabular}

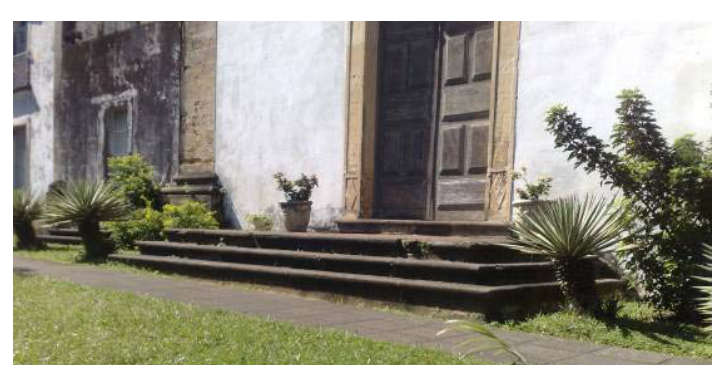

Image 16

Steps to access the church of Nossa Senhora da Graça 


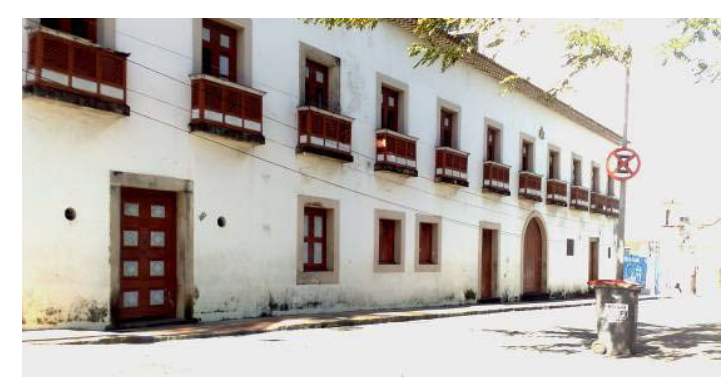

Image 17

Steps to access MASPE

Table 8

Paulista

\begin{tabular}{|c|c|c|c|c|}
\hline $\begin{array}{l}\text { Name of the } \\
\text { heritage }\end{array}$ & Type & 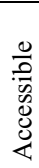 & 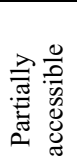 & 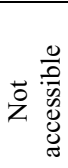 \\
\hline $\begin{array}{l}\text { Casa e Jardim do } \\
\text { Coronel }\end{array}$ & $\begin{array}{l}\text { Residence and } \\
\text { garden }\end{array}$ & & & $\mathrm{X}$ \\
\hline $\begin{array}{l}\text { Fortaleza de Pau } \\
\text { Amarelo }\end{array}$ & Fort & & & $\mathrm{X}$ \\
\hline
\end{tabular}

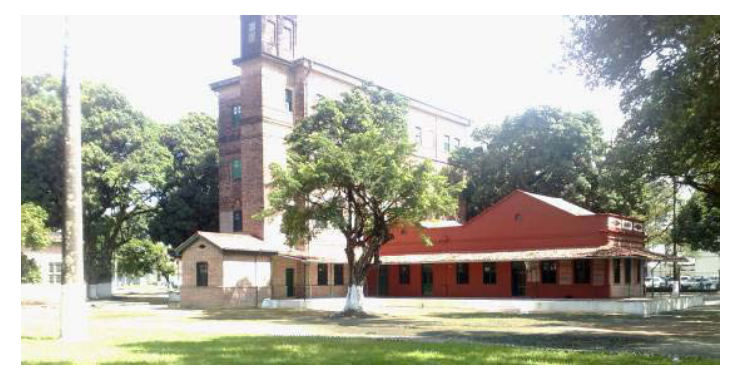

Image 18

Access steps to the house of Coronel

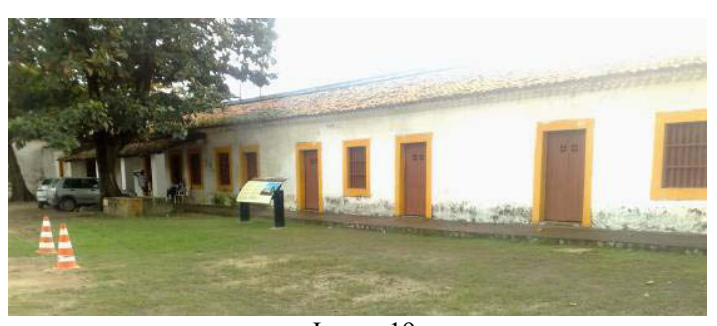

Image 19

Steps to access Fort of Pau Amarelo

The city of São Lourenço da Mata was represented by the sample of heritage listed on Table 10 .
Table 9

Recife

\begin{tabular}{|c|c|c|c|c|}
\hline $\begin{array}{l}\text { Name of the } \\
\text { heritage }\end{array}$ & Type & 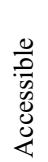 & 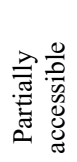 & 之 \\
\hline $\begin{array}{l}1 \text { Estação Ponte } \\
\text { D’Uchoa }\end{array}$ & Tram Station & & & $\mathrm{X}$ \\
\hline $\begin{array}{l}2 \text { Academia } \\
\text { Pernambucana de } \\
\text { Letras - Solar do } \\
\text { Barão Rodrigues } \\
\text { Mendes }\end{array}$ & $\begin{array}{c}\text { Residence / } \\
\text { Academy }\end{array}$ & & $\mathrm{X}$ & \\
\hline $\begin{array}{l}3 \text { Mercado de São } \\
\text { José }\end{array}$ & Market & & $\mathrm{X}$ & \\
\hline $\begin{array}{l}4 \text { Igreja de São } \\
\text { Pedro dos Clérigos }\end{array}$ & Church & & & $\bar{X}$ \\
\hline 5 Pátio de São Pedro & Courtyard & & $\mathrm{X}$ & \\
\hline $\begin{array}{l}6 \text { Museu da Cidade } \\
\text { do Recife }\end{array}$ & Fort / Museum & & $\mathrm{X}$ & \\
\hline $\begin{array}{l}7 \text { Igreja e Praça de } \\
\text { Boa Viagem }\end{array}$ & $\begin{array}{l}\text { Church and } \\
\text { Square }\end{array}$ & & $\mathrm{X}$ & \\
\hline $\begin{array}{l}8 \text { Ginásio } \\
\text { Pernambucano }\end{array}$ & School & & $\mathrm{X}$ & \\
\hline 9 Cinema São Luiz & Movies & & $\mathrm{X}$ & \\
\hline $\begin{array}{l}10 \text { Ponte da Boa } \\
\text { Vista }\end{array}$ & Bridge & & $\mathrm{X}$ & \\
\hline $\begin{array}{l}11 \text { Faculdade de } \\
\text { Direito }\end{array}$ & College & & $\mathrm{X}$ & \\
\hline $\begin{array}{l}12 \text { Teatro Santa } \\
\text { Isabel }\end{array}$ & Theater & & $\mathrm{X}$ & \\
\hline $\begin{array}{l}13 \text { Antiga Detenção } \\
\text { Casa da Cultura }\end{array}$ & $\begin{array}{l}\text { Prison / Craft } \\
\text { Centre }\end{array}$ & & $\mathrm{X}$ & \\
\hline $\begin{array}{l}14 \text { Terreiro Obá } \\
\text { Ogunte }\end{array}$ & $\begin{array}{c}\text { Temple of } \\
\text { African } \\
\text { Religion } \\
\end{array}$ & & & $\mathrm{X}$ \\
\hline 15 Torre Malakoff & Observatory & & $\mathrm{X}$ & \\
\hline $\begin{array}{l}16 \text { Igreja Madre de } \\
\text { Deus }\end{array}$ & Church & & & $\mathrm{X}$ \\
\hline 17 Quartel do Derby & Quarter & & & $\mathrm{X}$ \\
\hline $\begin{array}{l}18 \text { Antiga Escola de } \\
\text { Medicina - } \\
\text { Memorial de } \\
\text { Medicina de } \\
\text { Pernambuco }\end{array}$ & & & $\mathrm{X}$ & \\
\hline 19 Hospital Pedro II & Hospital & $\mathrm{X}$ & & \\
\hline $\begin{array}{l}20 \text { Estação Central } \\
\text { do Recife }\end{array}$ & $\begin{array}{l}\text { Railway Station } \\
\text { Cultural Center }\end{array}$ & $\mathrm{X}$ & & \\
\hline $\begin{array}{l}\text { 21 Casa de Oliveira } \\
\text { Lima - Conselho de } \\
\text { Cultura }\end{array}$ & $\begin{array}{c}\text { Residence - } \\
\text { Child Protection } \\
\text { Council }\end{array}$ & & & $\mathrm{X}$ \\
\hline $\begin{array}{l}22 \text { Palácio da Justiça } \\
\text { TJPE }\end{array}$ & Palace & & $\mathrm{X}$ & \\
\hline
\end{tabular}




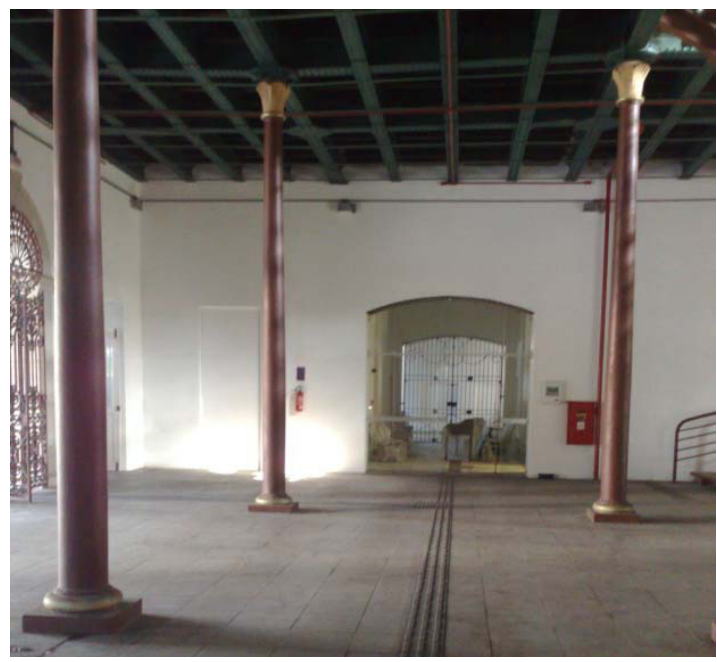

Image 20

Directional tread design from Central Station in Recife

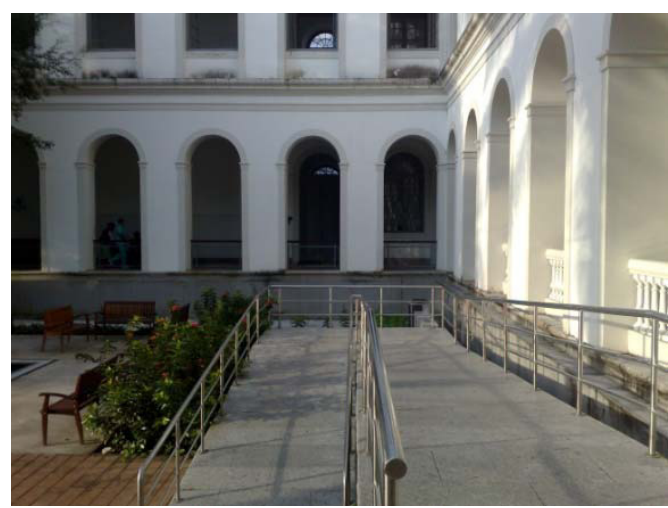

Image 21

Ramp of the Hospital Pedro II

Table 10

São Lourenço da Mata

\begin{tabular}{|c|c|c|c|c|}
\hline $\begin{array}{l}\text { Name of the } \\
\text { heritage }\end{array}$ & Type & 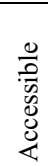 & 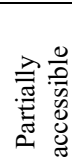 & Z \\
\hline $\begin{array}{l}\text { 1 Igreja Matriz de } \\
\text { Nossa Senhora da } \\
\text { Luz }\end{array}$ & Church & & & $\mathrm{X}$ \\
\hline $\begin{array}{l}2 \text { Estação } \\
\text { Ferroviária Tiúma }\end{array}$ & Railway Station & & & $\mathrm{X}$ \\
\hline
\end{tabular}

\section{Results and final remarks}

As general results were found that from the 46 heritages examined 2, approximately $(5 \%)$, are accessible, $16(35 \%)$ partially accessible and 28 $(60 \%)$ not accessible. Such data, although sample, confirmed that the majority of heritages do not provide access to a person physically disabled or with reduced mobility, signaling for professionals, institutions, managers and users about the need to reduce physical barriers in such places.

Even with the evolution of standards and legislations at various levels, in addition to the activities of prosecutors, there are still missing actions such as: dissemination of accessible routes, wider dissemination of the basic parameters of accessibility, inclusion of projects for people with special needs in the multi-annual plans of Iphan and Fundarpe, mitigation measures (virtual tours, videos, photo albums, etc..) while provide definitive solutions and preparation of manuals focusing on alternative solutions to the heritages.

The urgency of measures to ensure accessibility to public and private properties are increasingly needed as the Brazilian population is aging and is depriving themselves of knowing and access their cultural riches.

\section{References}

[1] Brasil, Constituição do. Assembléia Nacional Constituinte. Constituição do Brasil 1988. Recife, CEPE.(1989).

[2] Brasil, Secretaria Nacional de Transporte e da Mobilidade Urbana. Ministério das Cidades. Brasil Acessível. Programa Brasileiro de Mobilidade Urbana. (2006).

[3] Costa,Gabriela R.V. MAIOR, Izabel M.M. de L. e LIMA, Niusarete M. de . Acessibilidade no Brasil: uma visão histórica.III Seminário e II Oficina " Acessibilidade, TI e Inclusão digital" .São Paulo, 5 a 6 de 9/2005. bauru.apaebrasil.org.br/arquivo.phtml ?a=9446 -.Acessado em 4 /4/2011.

[4] FUNDAREPE, Fundação do Patrimônio Histórico e Artístico de Pernambuco. Patrimônios de Pernambuco: Materiais e Imateriais.Recife: Fundarpe,(2009).

[5] Gerente, Melissa M. , ELY, Vera Helena Moro Bins. Diretrizes de projeto para acessibilidade em sítios históricos:porque o patrimônio brasileiro é de todos e para todos.ABERGO 2006, Curitiba, PR.29 out./2 nov.Anais do $14^{\circ}$ Congresso Brasileiro de Ergonomia.

[6] Iida, Itiro. Ergonomia Projeto e Produção.São Paulo, Editora Edgard Blücher Ltda. (2002).

[7] Instrução Normativa $\mathrm{N}^{\mathrm{o}}$ 1(2010)http://www.cultura. gov.br/site/2011/04/26instrucao-normativa-n-1-2010-indice/

[8] Paiva, Carlos Magno de Souza. MIRANDA, Marcos Paulo de Souza. Direito do Patrimônio Cultural. Ouro Preto:UFPO,( 2011).

[9] Pernambuco, Constituição do Estado de.Constituição do Estado de Pernambuco 1989.Recife, CEPE, 1989. 
[10]TURISMO acessível:Mapeamento e planejamento. Acessibilidade em destinos turísticos.Volume II- Brasília: Ministério do Turismo, (2009),52p. www.turismo.gov. br Acesso em 4/7/2011. 